
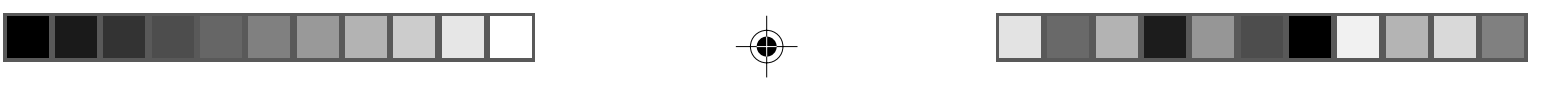

\title{
POSITION I
}

\section{DIALOGENS UDFORDRINGER}

\author{
ANITA HOLM RIIS
}

Ordet ,dialog' bliver ofte brugt til at signalere imødekommenhed, når en konflikt har gjort det nødvendigt at tale sammen. I forbindelse med Muhammedkrisen blev det fx flittigt anvendt af dem, som ønskede en forsoning. Set fra et bestemt hermeneutisk perspektiv er dialogen dog ikke bare forbundet med det at tale sammen. Begrebet dækker over en ganske sarlig samtaleform, som ikke uden videre indfinder sig. I Hans-Georg Gadamers filosofiske hermeneutik finder man en række overvejelser, der knytter sig til dette særlige dialogbegreb. Skal man undgå at opbygge barrierer imellem det, vi i daglig tale kalder 'kulturer', rummer dette begreb om dialog stof til eftertanke. Uagtet kulturbegrebets kompleksitet anvendes 'kultur' ofte som en betegnelse for det, vi erfarer som anderledes eller forskelligt fra det, vi selv repræsenterer. Denne erfaring ændres netop gennem dialogen, således at vi ikke længere kan tale entydigt om 'dit' og 'mit'.

For at kunne indlede en dialog må vi først og fremmest have en fælles sag. Sagen - altså det, dialogen handler om - er et vigtigt fikspunkt for de talende parter. Derfor er det afgørende, at parterne faktisk også taler om det samme. Vi kender alle de situationer, hvor en samtale mislykkes, fordi vi uden at være klar over det taler om noget helt forskelligt. Vi har forsøgt at få svar på helt forskellige spørgsmål, vore respektive interesser har været forskellige. Gadamer påpeger netop, at den fælles interesse i en given sag altid udspringer af et mere eller mindre eksplicit stillet spørgsmål, som de talende parter forenes om og i. Tanken er den, at vi egentlig kun taler rigtigt sammen, når den sag, vi taler om, udspringer af interesse for det samme spørgsmål. Den type situationer, hvor samtalen 'går skævt', vil kunne forklares under henvisning til, at de talende parter ikke har en fælles sag. Måske taler de om to forskellige ting uden at være klar over det, eller måske er en af parterne styret af interesser, som gør det uklart, hvad sagen egentlig går ud på. Derfor er åbenhed en helt afgørende forudsætning for dialog (Riis 2006). 

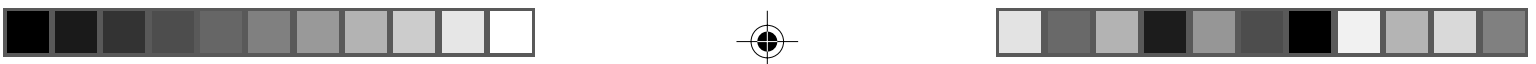

Åbenhed handler dog ikke bare om, at vi kender til hinandens forudsætninger. Den hænger basalt set sammen med det at være villig til at revidere sine antagelser. Gadamer taler om ,at sætte sine fordomme på spil““(2004:285). Møder vi hinanden med kun det formål at overtale den anden til at se sagen fra ens eget ståsted, får dialogen trange kår. Er vi derimod ægte interesserede i den andens synspunkter, kan en udveksling begynde. Gadamers tænkemåde er gennemført dynamisk. Dialog handler om at være både lyttende og bidragende. En af hans pointer er, at begge parter forvandles i dialogen: „At komme til forståelse i samtalen er ikke blot at spille sig ud og at sætte sit eget standpunkt igennem, men en forvandling hen imod det fælles, hvor man ikke forbliver, hvad man var" (op.cit.359).

For at dialogen kan udfolde sig åbent, må man endvidere være opmærksom på følgende: Dialogen lever af ikke at være en styret proces. Vores fikspunkt er alene den fælles sag, og denne sag kan belyses ud fra alle tænkelige relevante bidrag. Og det kan ikke afgøres på forhånd, hvad der er relevant. Det viser sig først i situationen. Det betyder også, at dialogen ikke har noget på forhånd fastsat mål, bortset fra ønsket om forståelse.

Nu kan man jo allerede her spørge, om ikke denne åbenhed bygger på en idealiseret forestilling om forholdet imellem mennesker. Den nyligt afdøde amerikanske filosof Richard Rorty var ikke i tvivl: Dialog er en illusorisk forestilling om, at vi som mennesker skulle kunne ignorere vore særinteresser. Vi bruger altid hinanden til et eller andet, og dermed har samtale altid et på forhånd fastsat mål. Denne påstand har Rorty blandt andet argumenteret for $\mathrm{i}$ en diskussion med Jürgen Habermas (Rorty 2000). Men argumenterne (som jeg ikke kan gå nærmere ind på her) kunne lige så godt være rettet mod Gadamer. At der er interesser på spil, når vi taler sammen, kommer vi selvfølgelig ikke udenom. Det er den måde, man udfolder sin interesse på, der udgør den store forskel imellem en (som hos Gadamer og Habermas) dialogisk og en (som hos Rorty) strategisk tænkemåde. Som nævnt er dialogen fokuseret på en sag, der i videst muligt omfang skal belyses med henblik på at få udfoldet en forståelse. Det betyder, at der ikke på forhånd er lagt restriktioner ned over sagen, fx i form af ting, der ikke nævnes, selv om de kunne være relevante. Magtforhold og skjulte dagsordener er eksempler på sådanne restriktioner. Det er netop Rortys overbevisning, at enhver samtale vil være præget af en mere eller mindre eksplicit dagsorden. Man vil noget bestemt, og man tilrettelægger sit ordvalg strategisk i forhold til dette.

Rorty lægger sig (velvidende og fornøjet) ud med en hel filosofisk tradition. Et af de begreber, der hører den tyske filosofiske tradition til, er 'ligeværdighed'. En ægte dialog tilsidesætter sær- og magtinteresser. Den indeholder dermed også parternes evne til at udvise gensidig respekt. Men vi ved jo alle, at det i høj grad er både magt og mere eller mindre skjulte overlegenhedsfølelser, der dominerer 

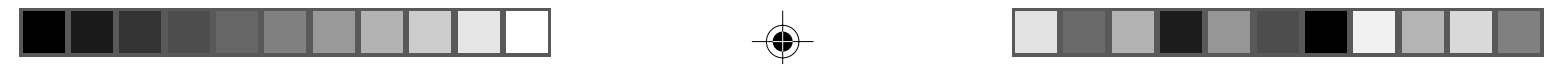

fx det politiske spil i dag. Så hvordan hænger det sammen? Uden at jeg her skal tage Gadamer til indtægt for følgende synspunkt, så ville mit svar være, at lige præcis fordi det ikke hænger sammen, er det vigtigt at tage dialogen alvorligt. Modstillingen mellem magt og dialog viser netop, at vi har brug for en tænkning, som bevarer vigtige grundlæggende idealer i vores samfund: ligeværd, respekt og dialog.

For nu at vende tibage til udgangspunktet - ønsket om at nedbryde barrierer imellem det, vi i daglig tale kalder 'kulturer' - så kan man naturligvis hævde, at en strategisk tænkning, hvor jeg på forhånd har en bestemt plan med den anden, kan være akkurat lige så barrierenedbrydende som en dialog - hvis jeg altså har held med at forme den anden i mit billede. Desværre er der både historisk og aktuelt masser af eksempler på, at en sådan strategi er et 'højt spil', som kan ende i konflikt. Det skyldes vel, at vi fundamentalt set ikke kan lide at blive manipuleret med. Og har man først haft den oplevelse, er dialog ikke nødvendigvis det første, man tænker på. Altså bliver den strategiske tænkning ikke bare et modstykke til dialogen - den direkte modarbejder den.

Muhammedkrisen viste ikke mindst, hvor svært det er at bevæge sig ind i dialogen på baggrund af en konflikt. Det kræver en overvindelse i modsætning til den dialog, vi uden videre træder ind i. I dialogen overlader vi os til noget, vi ikke selv styrer. Gadamer beskriver det som et spil, vi vikler os ind i. Spillet fungerer kun, når spillerne overlader sig til spillets gang. Det er dermed ikke den enkelte deltager, som sætter dagsordenen for den bevægelse, der foregår (Gadamer 2004:363). Spillet forløber som en integration, hvor vi tilpasser os hinanden. En spiller, som insisterer på at have sin egen dagsorden, ødelægger netop spillet.

Hvis vi ser på det, der foregår i Danmark, når flygtninge og indvandrere skal 'integreres', er der desværre mange eksempler på, at en dialogisk tænkning erstattes af en strategisk, som den Rorty taler om. For eksempel har der på det seneste været politisk fokus på at tiltrække højtuddannede udlændinge til Danmark. En hurtig unders $\varnothing$ gelse viste dog, at mindst 323 højtuddannede indvandrere fra lande uden for EU allerede befinder sig i Damark. De kører bus, taxa eller gør rent. Til en vis grad ligger det $i$ vore systemer eller i det offentlige system, hvis man kan tale om et sådant, at det må være strategisk ordnet. Som sådan kan man næppe bebrejde systemet, at der ikke har været overblik over arbejdsstyrken. Alligevel er det påfaldende, at vi først interesserer os for hinanden, når vi kan bruge hinanden til noget. Eksemplet her viser, at man langt tidligere kunne have været opmærksom på de højtuddannede indvandreres tilstedeværelse, hvis man havde interesseret sig for dem på en anden måde: hvis man fx havde været i dialog med dem om deres baggrund, uddannelse og kompetencer. Men det kræver selvfølgelig en grundlæggende anden måde at tænke på. 


\section{Litteratur}

Gadamer, Hans Georg

2004 Sandhed og metode. Grundtræk af en filosofisk hermeneutik. Viborg: Systime.

Riis, Anita Holm

2006 Kulturmødets hermeneutik. Højbjerg: Forlaget Univers.

Rorty, Richard

2000 Philosophie \& die Zukunft. Frankfurt a.M.: Fischer. 